Article

\title{
Impacts of Crapemyrtle Bark Scale on Consumers and the Horticulture Industry
}

\author{
Pulkit Marwah ${ }^{1}\left(\mathbb{D}\right.$, Yu Yvette Zhang ${ }^{1, *}$ and Mengmeng Gu ${ }^{2}(\mathbb{D}$ \\ 1 Department of Agricultural Economics, Texas A\&M University, College Station, TX 77843, USA; \\ pulkit.marwah91@tamu.edu \\ 2 Department of Horticultural Sciences, Texas A\&M AgriLife Extension Service, College Station, TX 77843, USA; \\ mgu@tamu.edu \\ * Correspondence: YZhang@tamu.edu
}

Citation: Marwah, P.; Zhang, Y.Y.; $\mathrm{Gu}, \mathrm{M}$. Impacts of Crapemyrtle Bark Scale on Consumers and the Horticulture Industry. Sustainability 2022, 14, 1857. https://doi.org/ $10.3390 /$ su14031857

Academic Editor: Imre J. Holb

Received: 1 January 2022

Accepted: 3 February 2022

Published: 6 February 2022

Publisher's Note: MDPI stays neutral with regard to jurisdictional claims in published maps and institutional affiliations.

Copyright: (C) 2022 by the authors. Licensee MDPI, Basel, Switzerland. This article is an open access article distributed under the terms and conditions of the Creative Commons Attribution (CC BY) license (https:// creativecommons.org/licenses/by/ $4.0 /)$.

\begin{abstract}
In this study, we conducted a nationwide online survey, including discrete choice scenarios, to understand consumers' purchasing behavior for flowering trees and shrubs for home landscapes in the US. In particular, we studied crapemyrtle, which is the most popular summer flowering tree in the US. This research evaluates the change in consumer willingness to pay for crapemyrtle plants due to pest infestation damage. Our study showed that the consumer willingness to pay (WTP) for crapemyrtles will decrease, due to the changes in their attributes, such as flower density and bark color, if infested by crapemyrtle bark scale (CMBS). We also analyzed the effect of consumers' personal characteristics, including their risk attitude, on their willingness to pay for crapemyrtle plants.
\end{abstract}

Keywords: flowering trees and shrubs; landscape; pest management; choice experiments; crapemyrtle; Lagerstroemia; willingness to pay

\section{Introduction}

The horticulture industry is an important part of the United States' economy. According to the recent USDA NASS Census of Horticultural Specialties, the value of all horticultural crops sold was over USD 13.7 billion [1]. Within the industry, crapemyrtle (Lagerstroemia spp.) is the most popular summer flowering tree [2-4]. Between 1998 and 2014, the total sales (by value) of crapemyrtles has almost doubled, from approximately USD 32.3 million to almost USD 67 million (Figure 1) [2-4]. In addition to a higher sales value, crapemyrtles also saw a very sharp increase in the total volume sold between 1998 and 2014, from approximately 1.9 million to over 4.8 million [2-4]. It is also widely grown in the United States [5,6]. According to the 2014 USDA NASS Census of Horticultural Specialties, 33 U.S. states, mostly in the southern part of the U.S., produce crapemyrtle (Figure 2) [4]. Crapemyrtles are widely popular in the U.S. due to their beauty, relative ease in growing, the availability of several varieties, and because they are comparatively pest resistant $[7,8]$. Due to the diversity on offer, in terms of use and varieties, crapemyrtle has earned the nickname "lilac of the south" [7].

Since crapemyrtles are valued for their aesthetic characteristics, any loss in their physical features would affect their value [6]. Pests, such as crapemyrtle bark scale (CMBS; Acanthococcus lagerstroemiae Borchsenius, 1960), can cause this [9].

Crapemyrtle bark scale has been reported in at least 14 U.S. states (Alabama, Arkansas, Florida, Georgia, Kansas, Louisiana, Mississippi, New Mexico, North Carolina, Oklahoma, Tennessee, Texas, Virginia, and Washington), and is threatening the production as well as the use of crapemyrtle in landscaping [9,10]. Crapemyrtle bark scale may result in reduced aesthetic value, such as sparse flowering, smaller flowers, and sooty mold covering the bark, stunted growth, or, in some cases, plant fatality $[9,11]$. 

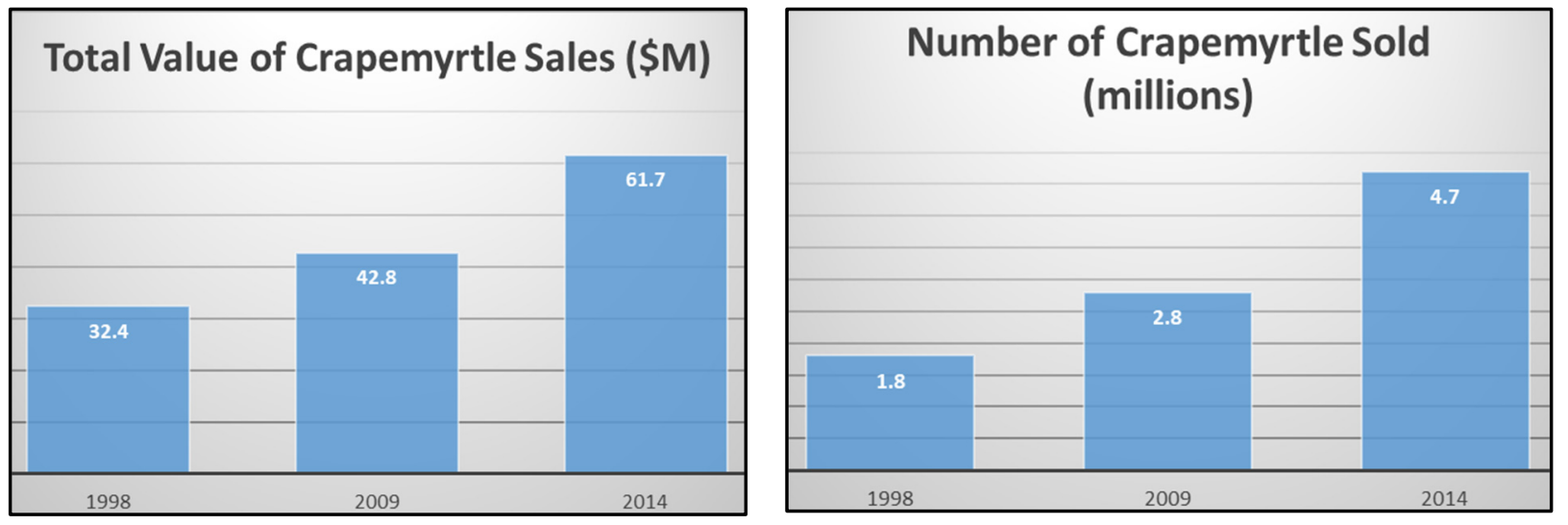

Figure 1. Historical data on crapemyrtle sales (USDA NASS Census of Horticultural Specialties 1998, 2009, 2014).

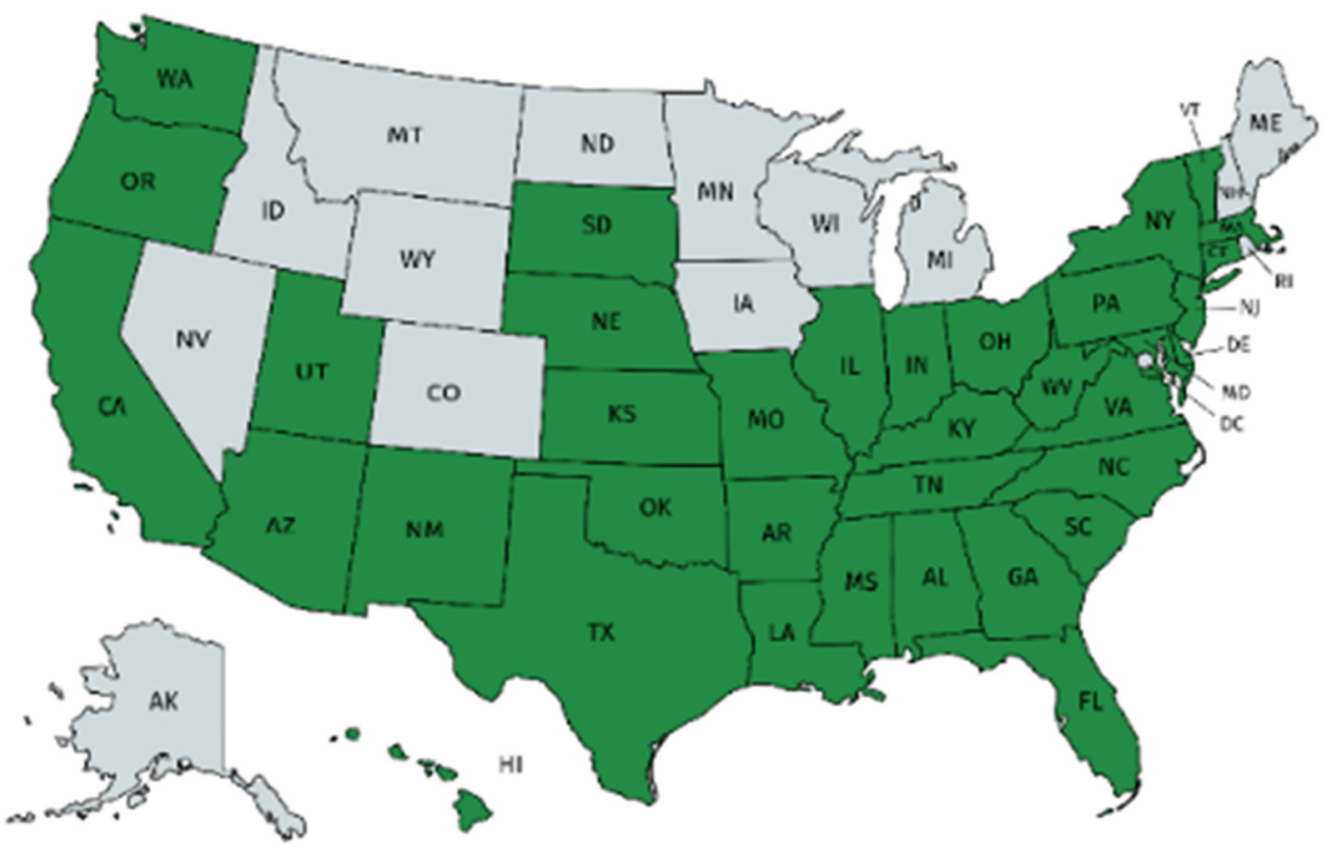

Figure 2. A map showing 33 crapemyrtle-producing states.

\section{Research Hypotheses}

Many stakeholders of the green industry, such as growers, retailers, landscapers, and consumers, are not aware of CMBS. Therefore, the production of crapemyrtle and its use in landscaping is expected to continue. This makes it extremely important to analyze the loss, caused by CMBS, to the horticulture industry. This study is aimed at studying the change in consumers' willingness to pay for plants (crapemyrtle), due to the loss of different physical characteristics. A product's attributes affect consumers' evaluation of the product [12]. A lot of resources have been spent on understanding consumers' decision-making process and factors influencing their valuation of products [13]. This research sets out to elicit consumers' willingness to pay (WTP) for important attributes affected by pest infestation. Extant literature consists of several studies that show that there is a negative correlation between plant purchasing and damage caused by pests [14-18].

Hypothesis 1. There is a decrease in the value of attributes affected by infestation. 
The main objective of this study is to evaluate the monetary impact of CMBS due to the loss of attributes in crapemyrtle plants. WTPs with a positive value would imply that consumers value the presence of attributes in crapemyrtle, which are absent in infested plants.

This study provides a measure of monetary value to the damages caused by pests. The results suggest which attributes are valued most by the consumers, based on the changes in WTP observed for the respective attributes.

Choice experiments can be used to learn about the attributes valued most by the consumers. Marginal WTPs for the attributes can be estimated based on the choices made by participants [19]. In designing choice experiments, it is important to include attributes that are relevant to consumers [20]. Extant literature shows that ornamental bark characteristics have contributed to the commercial success of crapemyrtles [7]. Additionally, it has been documented that flower coverage is an important driving force in horticultural research $[19,21]$. As detailed earlier, these attributes are also affected by CMBS [9,22]. We primarily focused on these while designing the choice experiment.

\section{Hypothesis 2. The consumers value different attributes unequally.}

The secondary objective of this study is to analyze the varied effect of pest infestation on different attributes of crapemyrtle plants. This can be achieved by calculating the marginal WTPs for the attributes.

Additionally, we also analyzed the effect of several personal characteristics, such as age, household size, gender, race, marital status, level of education, employment type, and income, on consumers' willingness to pay for crapemyrtle plants.

\section{Materials and Methods}

\subsection{Experimental Design}

We designed a survey about consumer demand and their preferences for crapemyrtle, using Qualtrics. We collected a nationally representative sample using an online survey platform-Amazon's Mechanical Turk (MTurk). Three selection parameters for choosing participants were applied: (a) must be at least 18 years of age (the default requirement to create an Amazon MTurk account), (b) location must be USA, and (c) the overall approval rate of participants' submissions must be over 95\%. Keywords such as "crapemyrtle", "plants", "flowers", "gardening", "landscape", and "horticulture" were used to target consumers with some knowledge of gardening and/or landscaping. We used the census data to collect a nationally representative sample, by individually collecting data for each state. Amazon MTurk has a pool of survey participants, who choose what surveys to participate in. By using the keywords, the participants who were interested in gardeningrelated surveys chose to participate in our survey, giving us a sample with participants who have knowledge/interest in gardening. In addition, there were attention check questions in the survey to screen participants for not meeting quality thresholds. The participants who chose to participate in our survey were presented with a consent form, followed by our survey. The study protocol was reviewed and approved by IRB (IRB No. IRB2017-0754D).

We used choice experiments with attributes of crapemyrtle plants to identify consumers' preferences for different traits affected by CMBS in order to estimate their demand for CMBS control. Choice experiments are used to elicit consumers' individual preferences for different attributes of a product. In choice experiments, the respondents are presented with multiple scenarios. In each scenario, the respondents make a choice between two options (each option has different attributes and price levels) and a third "neither" option. Through a series of such scenarios, the consumers' preferences for different attributes (and price levels) are elicited. The different attributes included in our survey (and the respective levels) are detailed in Table 1. 
Table 1. Attributes used in the choice experiment to analyze effect of CMBS.

\begin{tabular}{cc}
\hline Attribute & Levels \\
\hline Flowering & Sparse \\
& Dense \\
Bark color & Brown \\
& Sooty Black \\
Price & $\$ 200$ \\
& $\$ 250$ \\
& $\$ 300$ \\
\hline
\end{tabular}

As stated by Rihn, A.L. et al. [23], using choice experiments has several advantages, such as flexibility of attributes (flower density and bark color in our study) and price levels, understanding consumers' purchasing behavior, and the ability to identify the relative importance of different attributes [23,24]. Choice experiments have been used extensively in previous research to evaluate consumers' preferences and determine their willingness to pay (WTP) for horticultural products [23,25-28].

In the survey, the participants were presented with a hypothetical scenario and asked to choose between two options in the form of boxes with all the attributes listed, and a third "neither" option (Figure 3). We had 16 such scenarios, in a random order, with different combinations of attributes-bark color, flower density and price $(2 \times 2 \times 4=16)$.

Both trees described below have attained maturity and will not bloom/flower more than the current state. Now, hypothetically, you have to make a purchasing decision to buy a tree. Which buying option would you choose from each of the scenarios below? (choose one)

Plant A
Flowering: Sparse
Bark color: Sooty black
Price: $\$ 200$
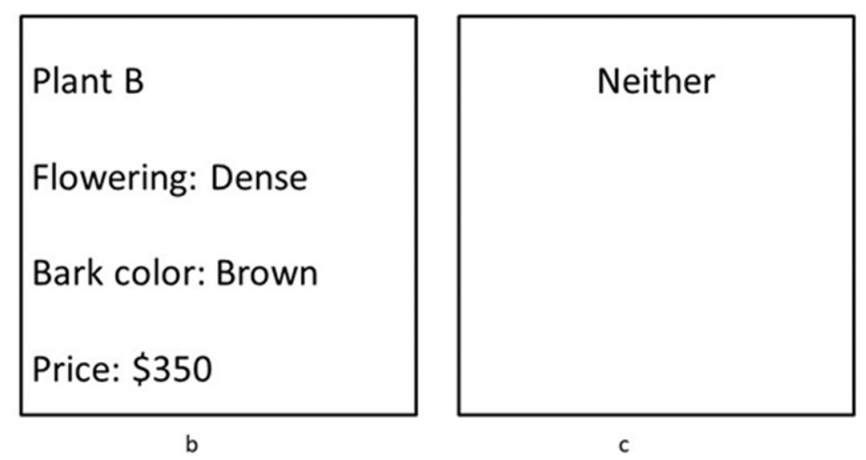

Figure 3. A choice scenario (with information boxes).

Varying groups of consumers behave differently when presented with purchasing decisions, specifically, the price they are willing to pay for a product. We also included consumers' personal characteristics in our analysis. We wanted to study the effects of consumers' personal characteristics on their willingness to pay for crapemyrtle plants. This can help the related businesses to adjust their marketing strategies based on consumers they aim to focus on, resulting in targeted marketing. Previous research indicates that there is a relationship between consumers' sociodemographic characteristics and their purchasing behavior $[26,28,29]$. Since the purchase of plants which might have different attributes (due to pest infestation, in this case) can be classified as a risky purchase, we also included consumers' risk aversion in our analysis [30]. Risk aversion is defined as "the extent to which people feel threatened by ambiguous situations, and have created beliefs and institutions that try to avoid these" [31]. Risk aversion is a factor that strongly affects consumers' decision-making process [32]. We employed the Eckel and Grossman task to elicit the participants' risk aversion [33]. A detailed account of the task as well as the elicitation of participants' risk aversion can be found in the work by Eckel and Grossman [33]. 


\subsection{Econometric Models}

As posited by Lancaster (1966), products are not the direct objects of utility, in fact, the utility that consumers' gain is derived from specific attributes of the product [34,35]. This study analyzes consumers' preferences for crapemyrtle plants. This analysis operates on the assumption that the participants are utility maximizers [19]. This is consistent with the theory of utility maximization by Lancaster [36]. In other words, for each scenario they were presented with, the participants chose the alternative that they preferred the most. This choice implies that they valued the attributes, mentioned in that alternative, more than other alternatives. Following this assumption, we can model the participants' choices using the random utility model (RUM) [37]. Under the RUM framework, an individual $\mathrm{i}$ chooses the option $\mathrm{j}$ from all the alternatives [19]:

$$
\mathrm{U}_{\mathrm{ij}}=\mu^{\prime} \cdot \mathrm{x}_{\mathrm{ij}}+\varepsilon_{\mathrm{ij}}
$$

where $\mathrm{x}$ represents a vector of individual characteristics, and $\varepsilon_{\mathrm{ij}}$ is the stochastic disturbance term $[19,34]$. The choice that an individual makes gives them the highest level of $U$. In essence, the participants chose the alternative that provided them with the highest utility in each scenario of the study.

Additionally, another assumption that this analysis makes is that subjects make a choice in a scenario independently of other scenarios presented to them [14]. The participants were presented with 16 scenarios in this study; in each scenario they made a choice between the alternatives without being influenced by their decision in the previous scenario, as well as their choice not influencing their decision in the following scenario. The first term in Equation (1) can be split into price and nonprice attributes [19,34,38]:

$$
\mathrm{U}_{\mathrm{ij}}=\alpha_{\mathrm{i}} \cdot \mathrm{p}_{\mathrm{ij}}+\sum_{\mathrm{k}=1}^{\mathrm{T}} \beta_{\mathrm{ij}} \cdot \mathrm{x}_{\mathrm{ijk}}+\varepsilon_{\mathrm{ij}}
$$

where $\mathrm{p}_{\mathrm{ij}}$ is the price of alternative $\mathrm{j}$ for individual $\mathrm{i}, \mathrm{x}_{\mathrm{ijk}}$ is the kth attribute of alternative $\mathrm{j}$ for individual $\mathrm{i}, \varepsilon_{\mathrm{ij}}$ is the stochastic disturbance term, and $\alpha_{\mathrm{i}}$ and $\beta_{\mathrm{ij}}$ are marginal utilities for price and kth attribute, respectively [31]. For our study, we were interested in two attributes related to crapemyrtles-bark color and flower density $(\mathrm{T}=2)$.

A consumer's willingness to pay (WTP) for the kth attribute is the amount of money the individual would be willing to pay to maintain their utility level when $\mathrm{k}$ changes from 0 to 1 [34]. In this study, we were interested in determining the consumers' WTP for flower density and bark color. Therefore, we are calculating the amount of money that a consumer would be willing to pay to derive the same utility, when the bark color attribute changes from sooty black (level $=0)$ to brown $($ level $=1)$; or when the flower density attribute changes from sparse (level $=0)$ to dense (level $=1)$. This can be considered as the premium that a consumer is willing to pay when an attribute improves from level $=0$ (sooty black bark color; sparse flower density) to level $=1$ (brown bark color; dense flowering). Based on Equation (1), the following equality holds [34]:

$$
\alpha_{\mathrm{i}} \cdot \mathrm{p}_{\mathrm{ij}}+\sum_{\substack{1=1 \\ 1 \neq \mathrm{k}}}^{\mathrm{T}} \beta_{\mathrm{il}} \cdot \mathrm{x}_{\mathrm{ijl}}+\beta_{\mathrm{ik}} \cdot \mathrm{x}_{\mathrm{ij}(\mathrm{k}=0)}=\alpha_{\mathrm{i}} \cdot\left(\mathrm{p}_{\mathrm{ij}}+\mathrm{WTP}^{\mathrm{k}}\right)+\sum_{\substack{1 \\ 1 \neq 1 \\ 1 \neq \mathrm{k}}}^{\mathrm{T}} \beta_{\mathrm{il}} \cdot \mathrm{x}_{\mathrm{ijl}}+\beta_{\mathrm{ik}} \cdot \mathrm{x}_{\mathrm{ij}(\mathrm{k}=1)}
$$

Solving the above inequality, Equation (3), the WTP is calculated by the following

$$
\mathrm{WTP}^{\mathrm{k}}=-\beta_{\mathrm{ik}} / \alpha_{\mathrm{i}} \cdot\left(\mathrm{x}_{\mathrm{ij}(\mathrm{k}=1)}-\mathrm{x}_{\mathrm{ij}(\mathrm{k}=0)}\right)
$$

Assuming a linear utility function, a consumer's WTP for the kth attribute is the negative ratio of the kth attribute's parameter to the price parameter [34]:

$$
\mathrm{WTP}^{\mathrm{k}}=-\beta_{\mathrm{ik}} / \alpha_{\mathrm{i}}
$$


We used a mixed logit model to determine consumers' preferences and WTP for different attributes, as well as WTPs for individuals in different groups based on personal characteristics [38-41].

\section{Results}

\subsection{Demographics}

We collected data from 8089 participants, from all 50 states and Washington D.C., between September 2019 and May 2021. We also included questions on personal characteristics, such as basic demographic information including age, gender, education, race, income, and type of residence, in our survey. Table 2 illustrates the summary statistics of the demographic information. The descriptive characteristics of our survey participants are as follows. The sample consisted of $43.82 \%$ female participants, with a mean age of 37.21 years. In addition, $65.14 \%$ of the participants had attended at least some college or had an associate's or a bachelor's degree. Additionally, 89.31\% of the participants were employed, with either part time or full time jobs. In addition, $68.04 \%$ of the participants lived in a house/duplex. The average annual income reported in our survey was $\$ 69,914.08$.

\subsection{Change in Consumers' Willingness-to-Pay Due to Pest Infestation}

From our statistical analysis of the mixed logit model, we were able to isolate the value, for the consumers, of the loss of attributes in the plants. The metrics in Table 3 illustrate that consumers value the presence of attributes in crapemyrtle, such as dense flowering, which are absent in plants infested with CMBS (Hypothesis 1).

We were also able to discern the relative importance of different crapemyrtle attributes, for the consumers, by employing the marginal WTPs (Hypothesis 2). Consumer WTP for crapemyrtle significantly decreased due to CMBS infestation, with dense flowering being the more valued attribute (highest WTP), compared to brown bark. The results indicate that consumers are willing to pay a higher price (USD 135.36) for densely flowered trees. They are also willing to pay a higher price (USD 20.37) for healthy brown bark. Overall, the consumers are willing to pay a higher price (USD 155.73) for a plant with attributes unaffected by infestation. This is a very important result, since the average price of a healthy tree is USD 300 in the retail market. In summary, there is a $51.91 \%$ decrease in the value of crapemyrtle resulting from loss of attributes that are commonly affected by CMBS.

We also found that WTPs for different attributes varied based on individual characteristics. For instance, female consumers and white consumers had a higher WTP as compared to male and non-white consumers, respectively (Table 3). Similarly, married consumers and consumers with children exhibited a lower WTP compared to unmarried (single/divorced/separated) consumers and consumers without children, respectively. Additionally, the consumers' WTP decreased as their household size increased. In addition, as the consumers moved towards higher education, and full time employment, their WTP decreased. In terms of reported income, the WTP followed a U-shape curve, with higher WTP for consumers in the "less than USD 30,000" and "USD 100,000 or more" categories, while the consumers in the "USD 50,000 to USD 59,999" exhibited the lowest WTP. There was also a difference in WTPs based on consumers' age group, as detailed in Table 3.

Table 2. Summary statistics of demographic information.

\begin{tabular}{cc}
\hline Variable & Mean (sd) \\
\hline Age (in years) & $\mathbf{3 7 . 2 1}(\mathbf{1 1 . 4 1 )}$ \\
Min & 18 \\
Max & 93 \\
Gender & Percentage \\
Female & $43.82 \%$ \\
Male & $55.89 \%$ \\
Other & $0.28 \%$ \\
\hline
\end{tabular}


Table 2. Cont.

\begin{tabular}{|c|c|}
\hline Variable & Mean (sd) \\
\hline Education & Percentage \\
\hline Regular high school diploma, GED or equivalent & $6.92 \%$ \\
\hline Some college, associate's degree, or bachelor's degree & $65.14 \%$ \\
\hline Master's degree, professional degree or doctorate degree & $27.52 \%$ \\
\hline Others & $0.42 \%$ \\
\hline Employment & Percentage \\
\hline Do not work & $7.39 \%$ \\
\hline Full time & $77.38 \%$ \\
\hline Part time & $11.93 \%$ \\
\hline Other & $3.16 \%$ \\
\hline Race & Percentage \\
\hline White & $75.72 \%$ \\
\hline Black & $15.63 \%$ \\
\hline Asian & $6.33 \%$ \\
\hline American Indian or Alaska Native & $1.83 \%$ \\
\hline Native Hawaiian or Pacific Islander & $0.49 \%$ \\
\hline Hispanic & $24.22 \%$ \\
\hline Type of Residence & Percentage \\
\hline Owned House/Duplex & $51.64 \%$ \\
\hline Owned Apartment/Condo/Loft & $12.55 \%$ \\
\hline Rented Apartment/Condo/Loft & $18.64 \%$ \\
\hline Rented House/Duplex & $16.40 \%$ \\
\hline Income (in USD) & USD $69,914.08(58,609.28)$ \\
\hline Median & USD 55,000 \\
\hline Less than USD 30,000 & $17.02 \%$ \\
\hline USD 30,000 to USD 49,999 & $23.37 \%$ \\
\hline USD 50,000 to USD 59,999 & $15.90 \%$ \\
\hline USD 60,000 to USD 69,999 & $8.25 \%$ \\
\hline USD 70,000 to USD 79,999 & $10.48 \%$ \\
\hline USD 80,000 to USD 89,999 & $5.44 \%$ \\
\hline USD 90,000 to USD 99,999 & $5.56 \%$ \\
\hline USD 100,000 to USD 149,999 & $9.16 \%$ \\
\hline USD 150,000 to USD 249,999 & $3.92 \%$ \\
\hline USD 250,000 or more & $1.89 \%$ \\
\hline Total Subjects & 8089 \\
\hline
\end{tabular}

Table 3. Mixed logit estimates and WTPs for different crapemyrtle attributes and individual characteristics.

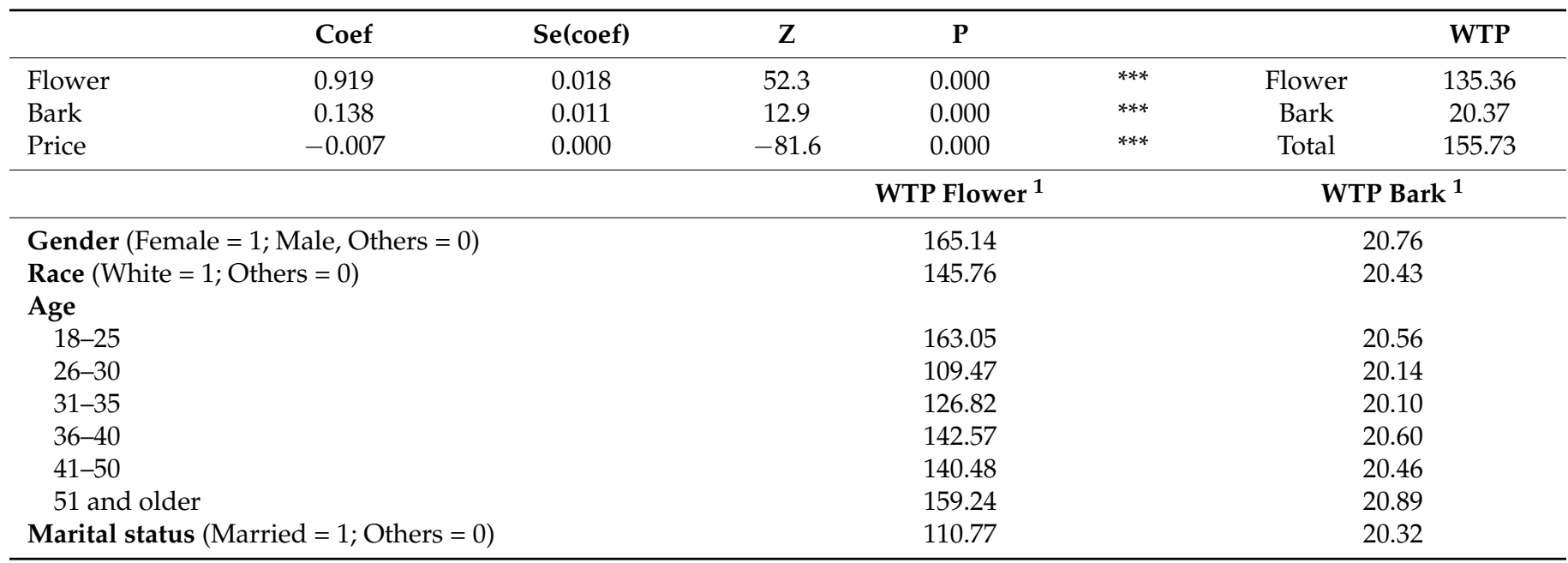


Table 3. Cont.

\begin{tabular}{lcc}
\hline & WTP Flower ${ }^{\mathbf{1}}$ & WTP Bark $^{\mathbf{1}}$ \\
\hline Income & & 20.16 \\
$\quad$ Less than USD 30,000 & 132.85 & 20.41 \\
USD 30,000 to USD 49,999 & 121.20 & 19.96 \\
USD 50,000 to USD 59,999 & 98.97 \\
USD 60,000 to USD 79,999 & 134.30 & 20.52 \\
USD 80,000 to USD 99,999 & 154.18 & 20.58 \\
USD 100,000 or more & 191.21 & 20.87 \\
Household size & & \\
1-2 & 207.38 & 20.93 \\
3 & 127.80 & 20.29 \\
4 & 106.28 & 20.31 \\
5 or more & 100.25 & 20.00 \\
Children (Yes = 1; No = 0) & 104.07 & 20.19 \\
Education & & \\
No schooling/high school/GED/others & 150.50 & 20.22 \\
Some college/associate's/bachelor's & 145.17 & 20.41 \\
$\quad$ Master's/professional/doctorate & 111.44 & 20.43 \\
Employment & & 20.2 \\
$\quad$ Full time & 117.40 & 20.87 \\
Part time & 181.01 & 21.08 \\
Others & 224.40 & \\
\hline
\end{tabular}

Signif. code: ${ }^{* * *} 0.001 .{ }^{1}$ WTPs for attributes based on individual characteristics.

\section{Discussion}

An important finding of this research is that the importance of different attributes affected by CMBS varies, and CMBS results in the overall loss in value of crapemyrtle. This would motivate researchers and public organizations to invest in CMBS control. It will also encourage the creation of effective communication/information material regarding CMBS and its control, for different stakeholders of the horticulture industry-producers, retailers, landscapers, and, most importantly, consumers. It is also important to note that curating sustainable control practices is of the utmost priority; since the current control strategies for CMBS include insecticides, particularly neonicotinoids, which risk pollinators [42]. It is important to note here that a limitation of this research is that our finding was a result of indirectly analyzing the effect of the loss of attributes in crapemyrtles due to CMBS on consumers' WTP for the plants. Future research may include direct analysis of the pests' impact.

\section{Conclusions}

The horticulture industry is an important part of the U.S. economy $[6,43,44]$. It is facing several challenges [43-45], a major one being pest infestation. Crapemyrtle, the main focus of this study, is no exception. Even though it is relatively pest free, CMBS results in the reduction/loss of its attributes. Extant literature has focused on studying the causal organism and mechanism of CMBS [11,46,47]. Additionally, it also sheds light on managing CMBS including systemic strategies, cleaning/washing, and scientific control strategies [8]. However, CMBS is an issue that needs to be dealt with, on multiple fronts. It is not enough just to focus on strategies to control it; there is an immediate need to evaluate its economic impact. It results in the loss of attributes such as flower density and bark color, which are of immense commercial value. The current study addresses this issue, and contributes to the current literature, by isolating the change in a plant's monetary value due to changes in its attributes. We did not want to negatively impact the consumers' responses by using words such as "damage" and "infested". This value was calculated to be over $46 \%$ of the plant's price. This provides producers with an estimate of the potential loss due to the infestation, and suggests the importance of effective CMBS control. Such economic analyses contribute towards increasing knowledge of CMBS, the importance of control 
strategies, and minimizing the potential loss caused by this pest to consumers, growers and the environment. Crapemyrtle bark scale can not only result in a decrease in crapemyrtle demand, it can also nudge the horticulture industry towards potential replacements. This provides important insights for producers in order to meet the demand of the consumers, and for the sustainable operation of businesses.

Our analysis also showed the effects of consumers' personal characteristics on their willingness to pay for crapemyrtle plants. For instance, whites, females, and consumers with smaller household sizes are willing to pay higher prices for crapemyrtle plants. This can help businesses to adjust their marketing strategies based on consumers they aim to focus on, resulting in targeted marketing.

Author Contributions: Conceptualization, Y.Y.Z. and M.G.; methodology, Y.Y.Z. and P.M.; software, Y.Y.Z. and P.M.; validation, Y.Y.Z. and P.M.; formal analysis, Y.Y.Z. and P.M.; investigation, Y.Y.Z. and P.M.; resources, Y.Y.Z. and M.G.; data curation, Y.Y.Z. and P.M.; writing—original draft preparation, P.M.; writing - review and editing, Y.Y.Z., M.G. and P.M.; visualization, P.M.; supervision, Y.Y.Z. and M.G.; project administration, Y.Y.Z. and M.G.; funding acquisition, Y.Y.Z. and M.G. All authors have read and agreed to the published version of the manuscript.

Funding: This work is partially supported by the AmericanHort Horticultural Research Institute, Center for Applied Nursery Research, and the Specialty Crop Research Initiative project "Systematic Strategies to Manage Crapemyrtle Bark Scale, An Emerging Exotic Pest" (grant no. 2017-5118126831/project accession no. 1013059) from the U.S. Department of Agriculture (USDA) National Institute of Food and Agriculture. Any opinions, findings, conclusions, or recommendations expressed in this publication are those of the author(s) and do not necessarily reflect the view of the USDA.

Institutional Review Board Statement: The study was approved by the TAMU Institutional Review Board (IRB2017-0754D, 10/31/2017).

Informed Consent Statement: Informed consent was obtained from all subjects involved in the study.

Data Availability Statement: Data sharing not applicable.

Acknowledgments: We acknowledge CMBS team members (stopcmbs.com) for their input and help with the design of the questionnaires.

Conflicts of Interest: The authors declare no conflict of interest.

\section{References}

1. USDA NASS Census of Horticultural Specialties. 2019. Available online: https://www.nass.usda.gov/Publications / AgCensus / 2017/Online_Resources/Census_of_Horticulture_Specialties/index.php (accessed on 8 July 2019).

2. USDA NASS Census of Horticultural Specialties. 1998. Available online: https://agcensus.library.cornell.edu/census_parts/19 97-horticulture/ (accessed on 8 July 2019).

3. USDA NASS Census of Horticultural Specialties. 2009. Available online: https://agcensus.library.cornell.edu/census_parts/20 07-census-of-horticultural-specialties / (accessed on 8 July 2019).

4. USDA NASS Census of Horticultural Specialties. 2014. Available online: https://agcensus.library.cornell.edu/census_parts/20 12-2014-census-of-horticultural-specialties / (accessed on 8 July 2019).

5. Marwah, P.; Zhang, Y.Y.; Gu, M. Effect of Crapemyrtle Bark Scale on Crapemyrtle Industry and Consumer Demand. In Proceedings of the 2019 Agricultural and Applied Economics Association Annual Meeting, Atlanta, GA, USA, 21-23 July 2019; (No. 291310). Available online: https://ageconsearch.umn.edu/record/291310/files/Abstracts_19_05_15_17_33_57_79_165_91_146_5_0.pdf (accessed on 25 May 2021).

6. Marwah, P.; Zhang, Y.Y.; Gu, M. Investigating producers' preferences for crapemyrtle and their perceptions regarding crapemyrtle bark scale. Horticulturae 2021, 7, 146. [CrossRef]

7. Pooler, M. Crapemyrtle. In Flower Breeding and Genetics; Anderson, N.O., Ed.; Springer: Dordrecht, The Netherlands, 2007; pp. 439-457. [CrossRef]

8. Gu, M.; Merchant, M.; Robbins, J.; Hopkins, J. Crape Myrtle Bark Scale: A New Exotic Pest. Available online: https://www. eddmaps.org/cmbs/Resources/TAMUCrapemrytlebarkscaleEHT-049.pdf (accessed on 8 July 2019).

9. Gu, M. Alternative Hosts of Crapemyrtle Bark Scale. Available online: https://cdn-ext.agnet.tamu.edu/wp-content/uploads/20 18/10/EHT-103-alternative-hosts-of-crapemyrtle-bark-scale.pdf (accessed on 8 July 2019).

10. Gu, M.; Department of Horticultural Sciences, Texas A\&M AgriLife Extension Service, College Station, TX, USA. Personal Communication, 2021. 
11. Wang, Z.; Chen, Y.; Diaz, R. Temperature-dependent development and host range of crapemyrtle bark scale, Acanthococcus lagerstroemiae (Kuwana) (Hemiptera: Eriococcidae). Fla. Entomol. 2019, 102, 181-186. [CrossRef]

12. Zhang, Y.; Jin, S.; Zhang, Y.Y.; Yu, X. How Country-of-Origin Influence Chinese Consumers' Evaluation for Imported Milk? China Agric. Econ. Review. 2021, 5, 150-172. [CrossRef]

13. Kassas, B.; Palma, M.; Zhang, Y.Y. The role of incentives on preference revelations in auctions versus rankings. J. Choice Model. 2016, 20, 73-85. [CrossRef]

14. Gardener, J.G.; Eastwood, D.B.; Brooker, J.R.; Klingeman, W.E. Consumers' valuation of disease resistant nursery stock. A case study of dogwoods. J. Agribus. 2003, 21, 103-116.

15. Sadof, C.S.; Raupp, M.J. Consumer attitudes toward the defoliation of American Arborvitae, Thuja occidentalis, by bagworm, Thyridopteryx ephemeraeformis. J. Environ. Hortic. 1987, 5, 164-166. [CrossRef]

16. Sadof, C.S.; Alexander, C.M. Limitations of cost-benefit-based aesthetic injury levels for managing two spotted spider mites (Acari: Tetranychidae). J. Econ. Entomol. 1993, 86, 1516-1521. [CrossRef]

17. Behe, B.; Hardy, J.; Barton, S.; Brooker, J.; Fernandez, T.; Hall, C.; Hicks, J.; Hinson, R.; Knight, P.; McNiel, R.; et al. Landscape plant material, size, and design sophistication increase perceived home value. J. Environ. Hortic. 2005, 23, 127-133. [CrossRef]

18. Mason, S.C.; Starman, T.W.; Lineberger, R.D.; Behe, B.K. Consumer preferences for price, color harmony, and care information of container gardens. HortScience 2008, 43, 380-384. [CrossRef]

19. Chavez, D.; Palma, M.; Byrne, D.; Hall, C.; Ribera, L. Willingness to pay for rose attributes: Helping provide consumer orientation to breeding programs. J. Agric. Appl. Econ. 2020, 52, 1-15. [CrossRef]

20. Hensher, D.A. How do respondents process stated choice experiments? Attribute consideration under varying information load. J. Appl. Econom. 2006, 21, 861-878. [CrossRef]

21. Zlesak, D.C. Rose. In Flower Breeding and Genetics: Issues, Challenges and Opportunities for the 21st Century; Anderson, N.O., Ed.; Springer: Dordrecht, The Netherlands, 2006; pp. 695-740.

22. Pest Management Strategic Plan for Container and Field-Produced Nursery Crops [(PMSP) Coordinated by Southern Nursery Integrated Pest Management Working Group]. Available online: https://ipmdata.ipmcenters.org/documents/pmsps/ SNIPMnurserycrops2015.pdf (accessed on 8 July 2019).

23. Rihn, A.L.; Yue, C.; Hall, C.; Behe, B.K. Consumer preferences for longevity information and guarantees on cut flower arrangements. HortScience 2014, 49, 769-778. [CrossRef]

24. Lusk, J.L.; Shogren, J.F. Experimental Auctions. In Methods and Applications in Economic and Marketing Research; Cambridge University Press: Cambridge, UK, 2007.

25. Chung, S.J.; Vickers, Z. Long-term acceptability and choice of teas differing in sweetness. Food Qual. Prefer. 2007, 18, 963-974. [CrossRef]

26. James, J.S.; Rickard, B.J.; Rossman, W.J. Product differentiation and market segmentation in applesauce: Using a choice experiment to assess the value of organic, local, and nutrition attributes. Agric. Resour. Econ. Rev. 2009, 38, 357-370. [CrossRef]

27. Koelemeijer, K.; Oppewal, H. Assessing the effects of assortment and ambience: A choice experimental approach. J. Retail. 1999, 75, 319-345. [CrossRef]

28. Yue, C.; Jensen, H.H.; Mueller, D.S.; Nonnecke, G.R.; Bonnet, D.; Gleason, M.L. Estimating consumers' valuation of organic and cosmetically damaged apples. HortScience 2007, 42, 1366-1371. [CrossRef]

29. Depositario, D.P.T.; Nayga, R.M., Jr.; Zhang, Y.Y.; Mariano, R.D.E. Revisiting Cash Endowment and House Money Effects in an Experimental Auction of a Novel Agri-food Product in the Philippines. Asian Econ. J. 2004, 28, 201-215. [CrossRef]

30. Zhang, Y.Y.; Depositario, D.; Nayga, R. Possibility of losing own money promotes learning to reduce overbidding: Delayed payment in experimental auctions. PLoS ONE 2019, 14, e0213568. [CrossRef]

31. Hofstede, G.; Bond, M.H. Hofstede's culture dimensions: An independent validation using Rokeach's value survey. J. Cross-Cult. Psychol. 1984, 15, 417-433. [CrossRef]

32. Shimp, T.A.; Bearden, W.O. Warranty and other extrinsic cue effectson consumers' risk perceptions. J. Consum. Res. 1982, 9, 38-46. [CrossRef]

33. Eckel, C.C.; Grossman, P.J. Sex differences and statistical stereotyping in attitudes toward financial risk. Evol. Hum. Behav. 2002, 23, 281-295. [CrossRef]

34. Gao, Z.; Schroeder, T.C. Effects of label information on consumer willingness-to-pay for food attributes. Am. J. Agric. Econ. 2009, 91, 795-809. [CrossRef]

35. Lancaster, K.J. A new approach to consumer theory. J. Political Econ. 1966, 74, 132-157. [CrossRef]

36. Lancaster, K. Consumer Demand: A New Approach; Columbia University Press: New York, NY, USA, 1971.

37. McFadden, D. The measurement of urban travel demand. J. Public Econ. 1974, 3, 303-328. [CrossRef]

38. Train, K. Mixed logit with a flexible mixing distribution. J. Choice Model. 2016, 19, 40-53. [CrossRef]

39. Hole, A.R.; Stata Users Group. Mixed Logit Modeling in Stata-An Overview. In United Kingdom Stata Users' Group Meetings 2013; (No. 23); StataCorp LLC: Lakeway, TX, USA, 2013.

40. Almli, V.L.; Asioli, D.; Rocha, C. Organic consumer choices for nutrient labels on dried strawberries among different health attitude segments in Norway, Romania, and Turkey. Nutrients 2019, 11, 2951. [CrossRef]

41. Bazzani, C.; Palma, M.A.; Nayga, R.M., Jr. On the use of flexible mixing distributions in WTP space: An induced value choice experiment. Aust. J. Agric. Resour. Econ. 2018, 62, 185-198. [CrossRef] 
42. Thurmond, A.A. Defining and Mitigating the Impacts of Acanthococcus lagerstroemiae (Hemiptera: Eriococcidae) Management on Pollinators. Master's Thesis, Auburn University, Auburn, Al, USA, 2019.

43. Marwah, P.; Zhang, Y.Y.; Gu, M. Impacts of COVID-19 on the green industry. Horticulturae 2021, 7, 329. [CrossRef]

44. Gatson, S.N.; Cisneros, M.; Brown, R.; Aitkenhead-Peterson, J.A.; Zhang, Y.Y. Urban networks, micro-agriculture, and community food security. Circ. Econ. Sustain. 2021, 1-13. [CrossRef]

45. Lin, B.X.; Zhang, Y.Y. Impact of the COVID-19 pandemic on agricultural exports. J. Integr. Agric. 2020, 19, 2937-2945. [CrossRef]

46. Vafaie, E.K.; Knight, C.M. Bark and systemic insecticidal control of Acanthococcus (=Eriococcus) lagerstroemiae (crapemyrtle bark scale) on landscape crapemyrtles, 2016. Arthropod Manag. Tests 2017, 42, 1-2. [CrossRef]

47. Wang, Z.; Chen, Y.; Gu, M.; Vafaie, E.; Merchant, M.; Diaz, R. Crapemyrtle bark scale: A new threat for crapemyrtles, a popular landscape plant in the US. Insects 2016, 7, 78. [CrossRef] [PubMed] 